\section{Incidence and Prognostic Implications of Diplopia in Patients with Giant Cell Arteritis}

\section{To the Editor:}

Giant cell arteritis (GCA) is the most common systemic vasculitis, with an incidence increasing with advanced age ${ }^{1}$. Patients present with a systemic inflammatory syndrome with constitutional symptoms and/or with ischemic events resulting from vascular occlusion including temporary or permanent visual loss $1,2,3,4$. Another less-recognized ophthalmologic manifestation of GCA is diplopia. Previous studies reported diplopia to occur among $6-20 \%$ of patients with ophthalmic symptoms and in 3-8\% of unselected patients with $\mathrm{GCA}^{5,6,7}$. Diplopia, along with jaw claudication, is a symptom that correlates with a positive biopsy finding ${ }^{8}$. Diplopia might be temporary and thus might be missed.

We prospectively analyzed incidence, clinical presentation, and outcome of patients with diplopia at diagnosis within our prospective single-center GCA cohort (Basler Riesenzellarteriitis Kohorte: BARK). The center's institutional review board approved our study. Briefly, patients presenting at the University Hospital Basel with newly diagnosed GCA according to American College of Rheumatology criteria ${ }^{9}$ were included after having given informed consent. Demographic, clinical, laboratory, and radiologic (including vascular ultrasound ${ }^{10}$ ) data of all patients were recorded at diagnosis and during followup. All patients with ophthalmologic symptoms were referred to further detailed ophthalmologic and orthoptic examinations. Temporal artery biopsy is routinely performed at our institution, unless the patient refuses. We included in our analysis only patients who had binocular diplopia.

Student's t-test was used to compare demographic and laboratory data between GCA patients with and without diplopia at presentation. Fisher's exact test was used to compare categorical data. Analyses were performed using Prism Version 6 (GraphPad Software Inc.).

Between January 2010 and May 2013, 37 patients having newly diagnosed GCA were included in our cohort. Nine patients (27\%) presented with diplopia at diagnosis.

The patients with diplopia more often had extracranial vessel inflammation assessed by vascular ultrasound, and a tendency to a higher incidence of vision impairment at diagnosis (Table 1).

Ophthalmologic symptoms and findings of the 9 patients with GCA presenting with diplopia are summarized in Table 2. Eight patients with diplopia at diagnosis complained about preceding temporary diplopia. Only 1 patient had persistent diplopia (case 6 in Table 2). Orthoptic examination confirmed abduction deficit in 5/9 patients (cases 1, 4, 5, 6, and 9), and in 1 patient history was consistent with abduction deficit (case 7). One of the patients with confirmed abduction deficit initially presented with vertical diplopia followed by ipsilateral ptosis, compatible with unilateral oculomotor paresis (case 1). The additional ipsilateral abduction deficit occurred a few days later. Decompensated exophoria, which resolved after initiating GCA treatment, was the cause of diplopia in another patient (case 3 ). A resolved trochlear deficit was the cause of diplopia in 1 patient (case 8). Finally, in 1 patient the cause of diplopia could not be established (case 2). Two patients perceived diplopia as blurred vision (case 5) or unclear near-vision (case 6). In those patients, abduction deficit was confirmed only by orthoptic examination.

Overall, visual impairment and loss was diagnosed in 11 of 37 patients $(30 \%)$, in $4 / 9(44 \%)$ patients with diplopia, and in $7 / 28$ patients $(25 \%)$ without diplopia $(\mathrm{p}=0.4)$. In 3 patients with diplopia the visual field defects were due to anterior ischemic optic neuropathy (cases 3, 5, and 6); in 1 case central artery occlusion was the cause of the vision loss (case 9). Diplopia preceded visual loss in all these patients, and therapy was initiated only after visual loss occurred. Three of the 9 patients with diplopia underwent diagnostic magnetic resonance imaging, none of which showed ischemic lesions within the central nervous system. All patients in the diplopia group had vasculitic findings on cranial ultrasound.

Twenty-seven patients were treated with oral prednisone starting with $1 \mathrm{mg} / \mathrm{kg}$ body weight/day and tapered thereafter. Ten patients ( 5 patients in
Table 1. Patient characteristics at diagnosis.

\begin{tabular}{|c|c|c|c|}
\hline Characteristics & With Diplopia & Without Diplopia & $\mathrm{p}$ \\
\hline No. patients & 9 & 28 & \\
\hline $\operatorname{Sex}, \mathrm{n}(\%)$ & & & 0.23 \\
\hline Male & $5(56)$ & $8(29)$ & \\
\hline Female & $4(44)$ & $20(71)$ & \\
\hline Age, yrs, mean (range) & $76(65-79)$ & $74.5(53-92)$ & 1 \\
\hline \multicolumn{4}{|l|}{ Ischemic symptoms, $\mathrm{n}(\%)$} \\
\hline Amaurosis fugax & $0 / 9(0)$ & $1 / 28(3.5)$ & 1 \\
\hline Visual loss & $4 / 9(44)$ & $7 / 28(25)$ & 0.4 \\
\hline Headache & $6 / 9(67)$ & $21 / 28(75)$ & 0.68 \\
\hline Jaw claudication & $7 / 9(78)$ & $18 / 28(64)$ & 0.69 \\
\hline Scalp tenderness & $5 / 9(56)$ & $15 / 28(54)$ & 1 \\
\hline Tender temporal arteries & $4 / 9(44)$ & $13 / 28(46)$ & 1 \\
\hline $\begin{array}{l}\text { Claudication of extremitie } \\
1 / 9 \text { (11) }\end{array}$ & $1 / 9(11)$ & $3 / 28(11)$ & 1 \\
\hline \multicolumn{4}{|l|}{ Systemic symptoms, n (\%) } \\
\hline *PMR & $3 / 9(33)$ & $10 / 28(36)$ & 1 \\
\hline Weight loss & $4 / 7^{\circ}(57)$ & $21 / 27 *(78)$ & 0.35 \\
\hline Night sweats & $3 / 9(33)$ & $12 / 27 *(44)$ & 0.7 \\
\hline \multicolumn{4}{|c|}{ Laboratory results, mean (range) } \\
\hline Platelets, G/1 & $442(271-721)$ & $383.5(139-939)$ & 0.64 \\
\hline $\mathrm{ESR}, \mathrm{mm} / \mathrm{h}$ & $70(30-110)$ & $76 *(14-130)$ & 0.65 \\
\hline CRP, mg/l & $70.1 *(32.8-158.3)$ & $62(10.1-158.2)$ & 0.51 \\
\hline $\mathrm{AP}, \mathrm{U} / 1$ & $70 *(59-84)$ & $83 *(52-188)$ & 0.13 \\
\hline \multicolumn{4}{|l|}{ Ultrasound findings } \\
\hline Cranial involvement & 9/9 (100\%) & $20 / 28(71 \%)$ & 0.16 \\
\hline Extracranial involvement & $5 / 9(56 \%)$ & $5 / 28(18 \%)$ & 0.04 \\
\hline Biopsy results, n (\%) & & & 0.3 \\
\hline Positive & 9/9 (100) & $19 / 23^{+}(83)$ & \\
\hline Negative & $0 / 9(0)$ & $4 / 23^{+}(17)$ & \\
\hline
\end{tabular}

* Data not available for 1 patient. ${ }^{\circ}$ Data not available for 2 patients. ${ }^{+} 1$ patient refused biopsy, 4 biopsies were not diagnostic. ESR: erythrocyte sedimentation rate; CRP: C-reactive protein; AP: alkaline phosphatase; PMR: polymyalgia rheumatica. Cranial arteries: A. carotis communis, A. carotis interna, A. carotis externa, A. vertebralis, A. temporalis; extracranial arteries: A. subclavia, A. axillaris, A. femoralis communis, A. profunda femoris, A. femoralis superficialis, A. poplitea.

each group) received intravenous steroids with doses ranging from 300 $\mathrm{mg} /$ day up to $1000 \mathrm{mg} /$ day for a total duration of 3-4 days. Nine of these patients had visual manifestations, i.e., visual loss and/or diplopia. Six months after diagnosis, the mean prednisone dose was similar in the 2 groups: $7.5 \mathrm{mg} / \mathrm{day}$ (diplopia group) and $10 \mathrm{mg} /$ day (non-diplopia group), respectively $(\mathrm{p}=0.32)$. Two patients with diplopia and 4 patients without diplopia additionally received methotrexate as a steroid-sparing agent (10-15 mg/weekly). All patients with diplopia except 1 showed complete resolution of diplopia within a few days after initiation of treatment. One patient needed a prism correction for the remaining heteronymous diplopia because of esodeviation (case 6)

Overall, the incidence of diplopia at diagnosis of GCA was higher than previously reported ${ }^{5,6,7}$, affecting more than a quarter of all patients. This is most likely due to the prospective setting of our GCA cohort (including ophthalmologic data collection) and to the often temporary character of diplopia $^{6}$. Our data might suggest that ischemia of the extraocular muscle(s), given their carotid artery supply, and/or ischemia of the cranial nerves innervating orbital muscles may be responsible for diplopia in patients with GCA. The trend for a higher risk of vision loss in our patients with diplopia together with the results of previous studies ${ }^{11}$ support the notion that diplopia in the setting of GCA is a warning sign for subsequent vision loss.

Personal non-commercial use only. The Journal of Rheumatology Copyright @ 2014. All rights reserved. 
Table 2. Ophthalmologic findings of patients with diplopia.

\begin{tabular}{|c|c|c|c|c|c|c|}
\hline \multirow[t]{2}{*}{ Case } & \multirow[t]{2}{*}{ Sex } & \multirow[t]{2}{*}{ Age, yrs } & \multicolumn{2}{|c|}{ VA } & \multirow{2}{*}{$\begin{array}{l}\text { Ophthalmologic } \\
\text { Symptoms }\end{array}$} & \multirow{2}{*}{$\begin{array}{l}\text { Ophthalmologic } \\
\text { Diagnosis }\end{array}$} \\
\hline & & & OD & OS & & \\
\hline 1 & $\mathrm{f}$ & 65 & 1.2 & 1.2 & $\begin{array}{l}\text { Vertical temporary diplopia } \\
\text { of } 2 \text { weeks' duration followed by } \\
\text { hypotropia and ptosis, OD, and } \\
\text { then esodeviation and abduction } \\
\text { deficiency, OD }\end{array}$ & $\begin{array}{l}\text { Partial oculomotor deficit, } \\
\text { OD } \\
\text { Abduction deficit, OD }\end{array}$ \\
\hline 2 & $\mathrm{f}$ & 72 & 0.9 & 0.9 & $\begin{array}{c}\text { Temporary diplopia } \\
\text { (3 episodes within } 8 \text { days })\end{array}$ & Not known \\
\hline 3 & $\mathrm{~m}$ & 76 & 0.8 & 0.9 & $\begin{array}{l}\text { Temporary diplopia ( } 1 \text { episode, } \\
\text { 1-day duration), followed by } \\
\text { right inferior visual field loss, OD }\end{array}$ & $\begin{array}{l}\text { Decompensated exophoria } \\
\text { AION, OD }\end{array}$ \\
\hline 4 & $\mathrm{~m}$ & 75 & 0.7 & 0.7 & $\begin{array}{c}\text { Headache, followed by diplopia } \\
\text { a week later with a transient } \\
\text { 1-month duration }\end{array}$ & Abduction deficit, OD \\
\hline 5 & $\mathrm{~m}$ & 76 & 0.3 & 0.2 & $\begin{array}{c}\text { Blurred vision and } \\
\text { reading problems ( } 3 \text { days } \\
\text { duration), progressed to } \\
\text { vision loss, OU } \\
\text { Congruent paracentral scotoma } \\
\text { left inferior }\end{array}$ & $\begin{array}{l}\text { Abduction deficit, OS } \\
\text { (probably the cause } \\
\text { of blurred vision initially) } \\
\text { Suspected AION, OS } \\
\text { No CNS ischemia (MRI) }\end{array}$ \\
\hline 6 & $\mathrm{~m}$ & 76 & 0.8 & 0.9 & $\begin{array}{c}\text { Vision impairment, } \\
\text { OS preceded by unclear } \\
\text { near-vision within } 3 \text { days. } \\
\text { Persistent diplopia indicated } \\
\text { prism correction. }\end{array}$ & $\begin{array}{l}\text { Abduction deficit, OU } \\
\text { AION, OS }\end{array}$ \\
\hline 7 & $f$ & 77 & 1.0 & 1.0 & $\begin{array}{l}\text { Unclear vision, followed } \\
\text { by 1-3 episodes of temporary } \\
\text { horizontal diplopia per day } \\
\text { for a total of } 5 \text { days }\end{array}$ & $\begin{array}{l}\text { History compatible with } \\
\text { abduction deficit }\end{array}$ \\
\hline 8 & f & 80 & 1.0 & 1.0 & $\begin{array}{l}\text { Temporary vertical diplopia, } \\
\text { tilted images resolved immediately } \\
\text { after initiating prednisone therapy }\end{array}$ & $\begin{array}{l}\text { Suspected resolved } \\
\text { trochlear deficit }\end{array}$ \\
\hline 9 & $\mathrm{~m}$ & 69 & LP & 1.0 & $\begin{array}{l}\text { Black spots/flickering light } \\
\text { phenomena of } 4 \text { days' duration, } \\
\text { followed by progressive } \\
\text { irreversible visual loss, OD }\end{array}$ & $\begin{array}{l}\text { Abduction deficit, OD } \\
\text { Central artery } \\
\text { occlusion, OD }\end{array}$ \\
\hline
\end{tabular}

VA: visual acuity; LP: light perception; DD: differential diagnosis; OD: right eye; OS: left eye; OU: both eyes; AION: anterior ischemic optic neuropathy; CNS: central nervous system; MRI: magnetic resonance imaging.

Our findings illustrate that diplopia in the setting of suspected GCA is a common symptom, but that it is easily overlooked and thus needs to be carefully assessed. It may be worthwhile to evaluate diplopia as a diagnostic criterion in patients with suspicion of GCA within larger prospective cohorts.

MORITZ HAERING, BMed, Medical Outpatient Clinic; ANDREAS HOLBRO, MD, Division of Hematology; MARGARITA G. TODOROVA, MD; MARKUS ASCHWANDEN, MD, Division of Angiology, University

Hospital Basel, Basel; FRIEDERIKE KESTEN, MD, Medical Department, District Hospital Aarau; CHRISTOPH T. BERGER, MD, Medical Outpatient Clinic; ALAN TYNDALL, MD; DANIELA BENZ, MD, Division of Rheumatology; CHRISTOPH HESS, MD, PhD, Medical Outpatient Clinic; THOMAS DAIKELER, MD, Division of Rheumatology, University Hospital Basel, Switzerland. The following authors contributed equally to this work: M. Haering, A. Holbro, M.G. Todorova, C. Hess, and T. Daikeler.

Address correspondence to Dr. T. Daikeler, Division of Rheumatology, University Hospital Basel, Petersgraben 4, 4031 Basel, Switzerland.

E-mail: thomas.daikeler@usb.ch

\section{REFERENCES}

1. Gonzalez-Gay MA, Vazquez-Rodriguez TR, Lopez-Diaz MJ, Miranda-Filloy JA, Gonzalez-Juanatey C, Martin J, et al. Epidemiology of giant cell arteritis and polymyalgia rheumatica. Arthritis Rheum 2009;61:1454-61.

2. Berger CT, Wolbers M, Meyer P, Daikeler T, Hess C. High incidence of severe ischaemic complications in patients with giant cell arteritis irrespective of platelet count and size, and platelet inhibition. Rheumatology 2009;48:258-61.

3. Kawasaki A, Purvin V. Giant cell arteritis: an updated review. Acta Ophthalmol 2009;87:13-32.

4. Miller NR. Visual manifestations of temporal arteritis. Rheum Dis Clin North Am 2001;27:781-97.

5. Gonzalez-Gay MA, Garcia-Porrua C, Llorca J, Hajeer AH, Brañas F, Dababneh A, et al. Visual manifestations of giant cell arteritis. Trends and clinical spectrum in 161 patients. Medicine 2000;79:283-92.

6. Hayreh SS, Podhajsky PA, Zimmerman B. Ocular manifestations of giant cell arteritis. Am J Ophthalmol 1998;125:509-20.

7. Glutz von Blotzheim S, Borruat FX. Neuro-ophthalmic 
complications of biopsy-proven giant cell arteritis. Eur J Ophthalmol 1997;7:375-82.

8. Smetana GW, Shmerling RH. Does this patient have temporal arteritis? JAMA 2002;287:92-101.

9. Hunder GG, Bloch DA, Michel BA, Stevens MB, Arend WP, Calabrese LH, et al. The American College of Rheumatology 1990 criteria for the classification of giant cell arteritis. Arthritis Rheum 1990;33:1122-8

10. Aschwanden M, Kesten F, Stern M, Thalhammer C, Walker UA, Tyndall A, et al. Vascular involvement in patients with giant cell arteritis determined by duplex sonography of $2 \times 11$ arterial regions. Ann Rheum Dis 2010;69:1356-9.

11. Gonzalez-Gay MA, Blanco R, Rodriguez-Valverde V, Martinez-Taboada VM, Delgado-Rodriguez M, Figueroa M, et al. Permanent visual loss and cerebrovascular accidents in giant cell arteritis: predictors and response to treatment. Arthritis Rheum 1998;41:1497-504.

J Rheumatol 2014;41:7; doi:10.3899/jrheum.130983 